\title{
Analysis of Floating Net Cages on The Carrying Capacity of The Darma Reservoir
}

\author{
Awliya Tribhuwana $^{1, \text { a) }}$, Zaenal Muttaqin ${ }^{2, \text { b) }}$ and Ohan Farhan ${ }^{3, \text { c) }}$ \\ ${ }^{1,2,3}$ Engineering Faculty, Civil Engineering Program, Universitas Swadaya Gunung Jati Cirebon \\ a)tribhuwana69@gmail.com \\ b) zenestemte@gmail.com \\ c) ohan.farhan@yahoo.com
}

\begin{abstract}
Darma Reservoir functions as a reservoir for irrigation, fisheries, and recreational and sports facilities. Currently, it only functions for irrigation and fish farming by floating net ponds. The development of floating net frameworks was so rapid that it conflicted with reservoir management. This study aims to determine the density of the floating net framework of the sedimentation conditions of the Darma Reservoir and to determine the development of the sedimentation rate of the Darma Reservoir in relation to the service life of the reservoir characterized by reduced dead storage. The first step was carried out by surveying the presence of the number of floating net cages, the distribution of the feed, the percentage of feed demand, the carrying capacity of the reservoir, then a topographic survey of the depth of the Darma reservoir to determine the capacity, rate and volume of sediment deposits. This study used quantitative approach, it began with distributing questionnaire forms and measuring the depth of the reservoir. The current condition of floating net cages is 4916 occupying $5.819 \%$ of the inundation area of 312.15 ha with an elevation of $712.50 \mathrm{~m}$, while floating net cages are allowed according to the carrying capacity of Darma Reservoir waters amounting to 1,021. tons / harvest while the spawning pond is 3.483 tons/harvest. The volume of normal active storage for elevation 712.50 in 2020 is 28.086 million $\mathrm{m}^{3}$, while the volume of sediment deposits is 9.262 million $\mathrm{m}^{3} 32.98 \%$, the average sediment rate in the reservoir from 1988 to 2020 is 0.2894 million $\mathrm{m}^{3} / y e a r$, while the sediment rate in catchment area Dam Dharma with an area of $23.5 \mathrm{~km}^{2}$ of $71.873 \mathrm{~mm} /$ year. Sedimentation in the Darma Reservoir has exceeded the limit of the base elevation of the reservoir, the elevation of the dead reservoir and the lowest elevation, but the reservoir is still functional. The planning life of the darma reservoir is up to 50 years, the suitability of the initial planning of operations in 1970 with operations until 2020.
\end{abstract}

Keywords: Reservoir, floating cages, sedimentation, reservoir age

\section{INTRODUCTION}

Cultivating fish using a floating net framework (KJA) is one method used to meet food needs. Aquaculture using floating net cages (KJA) will cause changes in environmental conditions. [1]. This has a negative impact on the condition of the aquatic environment. [2]. Aquaculture using marine cage can cause various environmental impacts on water bodies. These negative impacts are in the form of sedimentation and eutrophication which can reduce the quality of reservoir waters. [3]. The decline in the quality of the reservoir waters is caused by excessive fish farming activities in the marine cage. [4]. [5] The problems that always arise with the existence of fish farming are the occurrence of mass fish mortality, disease outbreaks, and even a decline in fish farming production. Eutrophication [6] and 
sedimentation are the initial impacts arising from fish farming with the floating net cage [7]. Sedimentation in the Darma Reservoir according to the results of communication with fish cultivators showed that the reservoir depth varies from the inlet, middle, periphery and outlet of the reservoir. The inlet has a depth of $2-3 \mathrm{~m}$. The part of the waters with a high density of marine cage, the edges have a depth of 1-3 m. The portion of the reservoir water with a medium density of $3-4 \mathrm{~m}$. While the outlet section of the reservoir has a depth ranging from $5-10 \mathrm{~m}$.

Based on the problems above, the condition of Darma Reservoir which has several the floating net cages with varying density and has experienced sedimentation, it is necessary to conduct research on KJA sedimentation which affects the age of Darma Reservoir, so that this research is expected to provide the latest information about sedimentation conditions. Information on these conditions can be in the form of water sedimentation rates by the floating net cage and as a consideration for the Regional Government for the management of Darma Reservoir as well as recommendations to the community around the reservoir in the management and utilization of Darma Reservoir, the use of the floating net cage must pay attention to the impact of sedimentation caused by the KJA itself.

\section{RESERVOIR}

Reservoirs provide water to store water [8] in excessive periods for using during dry processes. The collected water is used for the purposes of providing irrigation water, raw water for drinking water, industry, electricity, or other uses. [9]. Reservoirs in Indonesia are used to support irrigation, raw water, flood control, and for power generation. The main part of the reservoir based on its function is divided into three main parts: the dead storage, effective storage, additional storage which is usually used for flood storage.

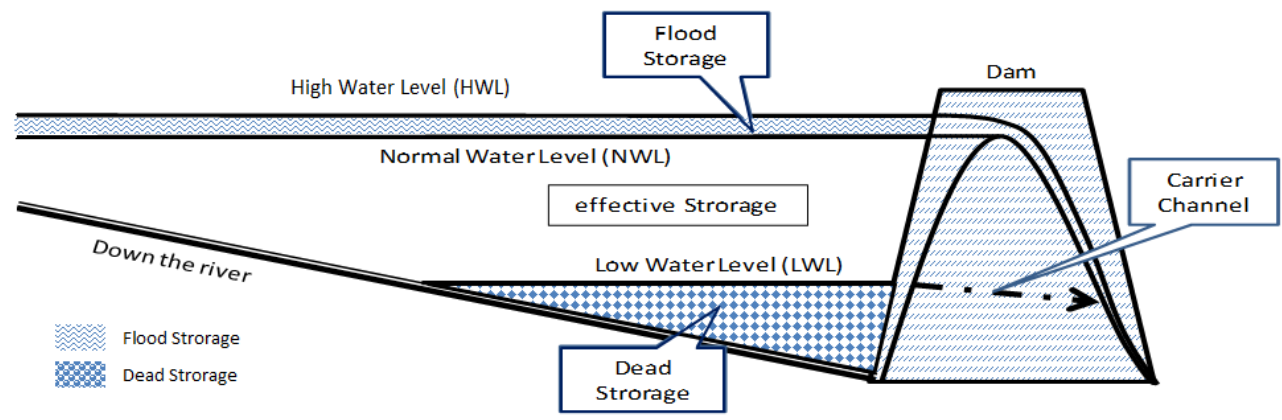

FIGURE 1. storage area in the reservoir

\section{RESERVOIR CAPACITY}

Reservoir capacity in natural position is determined based on topographic measurements. [10] adds that the capacity of a reservoir is determined by natural conditions or valleys so that water will be collected with the height of a dam which must accommodate the required amount of water and be economically available. Dam capacities vary from a few hundred hectare-meters on small rivers to millions of cubic meters. The water level in the reservoir can be different [11], depending on the inflow and the outflow from the reservoir. The main sources of inflows are rainfall and sources of outflows are surface runoff, evaporation, and infiltration. Normal pool level [12] is the maximum elevation achieved by the rise of the reservoir water level under normal operating conditions, and normal inundation is determined by the elevation of the overflow ledge or the top of the spillway gate. In addition, the minimum pool level is the lowest elevation when inundation is released under normal conditions. This surface can be determined by the elevation of the lowest discharge building within the weir, the volume of deposits located between the dead storage surfaces, useful storage and water held below the dead storage surface. During a flood, discharge through overflow can cause the water level to rise higher than the normal water level, added that the reservoir capacity [13] is below the lowest level of dead storage provided to accommodate the silt in the reservoir.

It can be estimated that the condition of the reservoir becomes muddy, the faster decrease of the reservoir capacity leads to the narrower reservoir [14]. The reservoir has a device to drive the mud out through the exit which is installed below the dead storage level line. The decrease in reservoir capacity by sedimentation depends on the amount of sediment that enters, the percentage of the captured sediment, the density of sediment that settles [15]. 


\section{METHODOLOGY}

The darma reservoir is a reservoir located in southwest of the Kuningan City, exactly at Jagara village, darma district on the causeway Cirebon Kuningan Ciamis. It occupies an area of \pm 425 hectare, surrounded by hills and valleys and a beautiful sight with cool air. Capacity for standing water at a maximum of $\pm 39,000000 \mathrm{~m} 3$, with distance of $12 \mathrm{~km}$ from the city of Kuningan and $37 \mathrm{~km}$ from the town of Cirebon. Quantitative data were collected using field surveys, this method of obtaining measurable and quantifiable data could describe a case of object research.

Survey data were needed to create meaningful studies, survey data were grouped by 3 . The first was the question forms to the floating net cages (KJA) farmers on needs of fish feed, manner and time feeding. The second was counting the number of floating net cages (KJA) in Darma reservoir. The third was surveying the depth of the reservoir. The deployment of the floating net cages (KJA) form leads to the management of feeding, frequency of feed, total age-based feed, feed distribution of floating net cages (KJA) Darma reservoir. The sum of floating net cages (KJA) Darma reservoir gave capacity to support power comes from calculating the percentage of $\mathrm{P}$ needs of the fish. The depth of the reservoir determines the capacity and pace of sedimentation while the operating age is based on the dam's construction.

\section{RESULT AND DISCUSSION}

\section{Condition of floating net cages}

The results of the 2020 survey of the waters of the Darma reservoir as in table 1. showed 6 (six) villages that have 4916 floating net cages, consisting of Jagara, Paninggihan, Cipasung, Kawah Manuk, Darma and Gombangan. The Darma Reservoir with an elevation of 712.50 has an area of 312.15 ha, while the area of the floating net cages covering the waters is 18.165 ha or $5.819 \%$ of the area of the reservoir waters.

The floating net cage system (KJA) carried out by the community is generally divided into units, where in 1 cage unit there are 4 (four) pond plots with the size of each plot $(6 \mathrm{~m} \times 6 \mathrm{~m})$, so that 1 plot of the karamba pond has an area $(6 \mathrm{~m} \times 6 \mathrm{~m} \times 4)=144 \mathrm{~m}^{2}$.

TABLE 1. The existence of Darma Reservoir Floating Net Cages

\begin{tabular}{|c|c|c|}
\hline Village & $\begin{array}{c}\text { The number of } \\
\text { pools }\end{array}$ & Spawning pond \\
\hline Jagara & 2521 & 67 \\
\hline Paninggaran & 883 & 46 \\
\hline Cipasung & 1068 & 8 \\
\hline Kawah Manuk & 123 & 4 \\
\hline Darma & 286 & 4 \\
\hline Gombangan & 35 & 0 \\
\hline Total & 4916 & 129 \\
\hline
\end{tabular}

\section{Analysis of the existence of a floating net framework}

The number of intensive marine cage units in Darma Reservoir based on the results of the 2020 survey was 4,916 KJA. The number of marine cage was taken with the assumption that there is no control of marine cage. The average fish production per KJA is 1.6 tonnes / harvest, so the total fish production is 1.6 tons $\mathrm{x} 4,916=7,866$ tons / harvest or 12,584.96 tons / year, assuming fish cultivators harvest 3 times a year. Based on the results of these calculations it can be concluded that there is an excess amount of fish production in the Darma reservoir with the allowable amount of fish production, namely (12,584.96 tons 121.979 tons $)=12,462.98$ tons / year or 6,231 tons / harvest assuming the harvest occurs as much as three times a year. Based on the results of these calculations, the maximum number of marine cages in the darma reservoir are 1,021 KJA plots. 
In connection with the results of the calculation of the carrying capacity of the reservoir, the maximum total number of KJA in Darma Reservoir is 1,021, the management and utilization associated with KJA business activities requires clear regulations so that in implementation it will not have a negative impact on the reservoir waters. The regulations that apply can be formal or informal. Regulations that are formal in nature such as laws (UU), ministerial regulations (Permen), ministerial decrees (Kepmen), regional regulations (Perda) of West Java Province, governor decrees of West Java, and regional regulations (Perda) Kuningan Regency. Meanwhile, informal regulations such as agreements between communities relating to the KJA Waduk Darma. Then, these regulations can come from government agencies and non-government institutions as agreed by the community.

\section{Feeding Management}

Table 2 shows the feed needs for KJA reservoir darma, for Jagara Village, the need for feed is 642,742 tons / harvest with the amount of pools is 2541 occupying the first place in feeding, followed by Cipasung village with the amount of feed of 272,292 tons / harvest with the amount 1068 ponds, for the smallest feed needs found in Gombangan village with a total feed requirement of 8.923 tons / harvest with a total of 35 ponds.

TABLE 2. Darma Reservoir Floating Net Cage Feed Spread

\begin{tabular}{lcccccc}
\hline \multicolumn{1}{c}{ Desa } & $\begin{array}{c}\text { Fish rearing pond } \\
\text { pools }\end{array}$ & $\begin{array}{c}\text { Feed/ } \\
\text { day }(\mathbf{K g})\end{array}$ & $\begin{array}{c}\text { amount of } \\
\text { feed } \\
\text { (Ton) }\end{array}$ & $\begin{array}{c}\text { Spawning } \\
\text { lots of } \\
\text { pools }\end{array}$ & $\begin{array}{c}\text { Feed/ } \\
\text { day } \\
\text { (Kg) }\end{array}$ & $\begin{array}{c}\text { amount of } \\
\text { feed (Ton) }\end{array}$ \\
\hline Jagara & 2521 & 254,96 & 642,742 & 67 & 27,00 & 1,809 \\
Paninggara & 883 & 254,96 & 225,125 & 46 & 27,00 & 1,242 \\
n & & & & & & 0,216 \\
Cipasung & 1068 & 254,96 & 272,292 & 8 & 27,00 & 0,108 \\
Kawah & 123 & 254,96 & 31,359 & 4 & 27,00 & 0,108 \\
Manuk & 286 & 254,96 & 72,917 & 4 & 27,00 & 0 \\
Darma & 35 & 254,96 & 8,923 & 0 & 27,00 & 3,483 \\
Gombangan & 4916 & Total & 1253,359 & 129 & Total \\
\hline \multicolumn{1}{c}{ amount } & & Feed & & & Feed
\end{tabular}

The order of percentage of feed needs for KJA reservoir darma is shown in Figure 2 below, the need for pond development for Jagara village is $51.28 \%$, Cipasung village $21.72 \%$, Paninggaran village $17.96 \%$, Darma village 5.82, Kawah Manuk 2 village, 50\% and Gombangan village 0.71\%, while the percentage of spawning pond feed needs in Jagara village is 51.94\%, Paninggaran village 35.66\%, Cipasung village $6.20 \%$, Darma village $3.10 \%$ and Manuk crater village $3.10 \%$, so it can be concluded that the average feed requirement for KJA in Darma reservoir once harvested in Jagara village is $51.61 \%$, Paninggaran village 26.81\%, Cipasung village 13.96\%, Darma village 4.46\%, Kawah Manuk $280 \%$, Gombangan village $0.36 \%$.

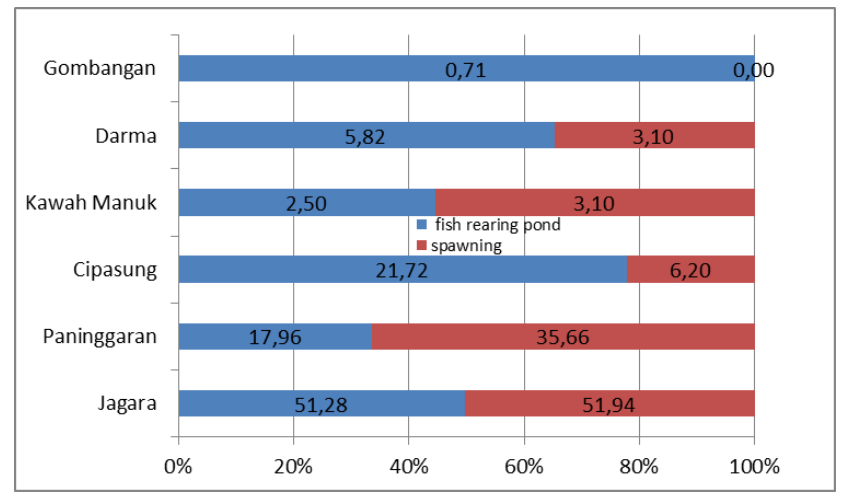

FIGURE 2. Food Demand Presentation for Darma Reservoir 
In feeding 1, the harvest period in the darma reservoir for 6 villages took up to 1253.36 tons with 4916 KJA the fish rearing pond, the spawning pool takes 3.483 tons with $129 \mathrm{KJA}$. The feeding differs according to the number of ponds available each village. As for the weight of the percentage of the feed of the water, the blue fish rearing pond and red spawning pool seen on figure 2.

\section{Darma Dam Capacity}

The capacity of water pollution load is the limit of the capacity of the water resource to accept the input of the pollution load which does not exceed the water quality requirement limits for various uses. Dam capacity, namely the ability of the Dam waters to accommodate the load of water pollution so that it meets water quality standards and trophic status. Darma Dam has a limit on the capacity of water quality in accordance with the Regulation of the Minister of the Environment Number 28 of 2009 concerning the Capacity to Carry the Load of Lake Water Pollution and / or Reservoirs. The results of the analysis showed that the total capacity $\mathrm{P}$ is $171.4 \mathrm{~kg} /$ year. These results explain that in 1 year the darma dam can only accommodate $171.4 \mathrm{~kg}$ of total $\mathrm{P}$ in the waters, while in the process in the existing Dharma $\mathrm{P}$ dam, there are a lot of inputs from the feed provided by KJA of $16.40 \mathrm{~kg} /$ year

Total $\mathrm{P}$ in fish feed given to Darma Dam was $6,408.66 \mathrm{mg} / \mathrm{m}^{2} /$ year. The result is a calculation of the multiplication of reservoir capacity to accommodate phosphorus from marine cage $\left(\mathrm{g} / \mathrm{m}^{3}\right)$, mean reservoir depth $(\mathrm{m})$, water flushing rate (year-1), with the divider of total phosphorus produced by fish from marine cage activity. Therefore, these conditions provide information that the capacity of phosphorus per unit area of the dam for fisheries in the darma dam

\section{Darma Dam Carrying Capacity}

The carrying capacity of KJA in the Dharma Dam is 2,000,463 tons / year. The number of intensive KJA plots in the Dharma Dam based on the results of the 2020 survey was 4916 KJA plots. Meanwhile, the average fish production was 1.6 tons / harvest, the result was 7,866 tons / harvest or 12,584.96 tons / year. Based on the results of these calculations, it can be concluded that there is an excess amount of fish production in Darma Dam, namely (12,584.96 tonnes - 121.9795 tonnes) $=12,462.98$ tonnes / year or 6,231 tonnes / harvest. with the carrying capacity of Darma Dam as much as 1,021 compartments of KJA.

When the standing water capacity was 39 million $\mathrm{m} 3$, an evaluation was carried out for the availability of floating net cages in the waters of the Darma Reservoir and the result was 1,500 KJA which could be approved. However, until now, the existence of KJA has increased until it reaches 4916 KJA. When analyzing the presence of marine cage with an inundation capacity of 28.664 million m3, the allowed number of marine cage is 1,021 compartments of floating marine cage. 0.03 , if divided by the inundation volume in 2020 of 28.66 million $\mathrm{m} 3$, the figure will be 1,102 , which can be used as the maximum limit for the number of marine cage in the darma reservoir. When compared with the analysis of volume volume in 2020 amounted to 28.66 with the number of KJA 1,021 smaller than 1,102.

\section{Capacity and Pace of Sedimentation Rate}

The results of the reservoir survey are topographical measurements of the surrounding inundation of the reservoir and the depth of the reservoir, so a contour map is made as shown in Figure 3.

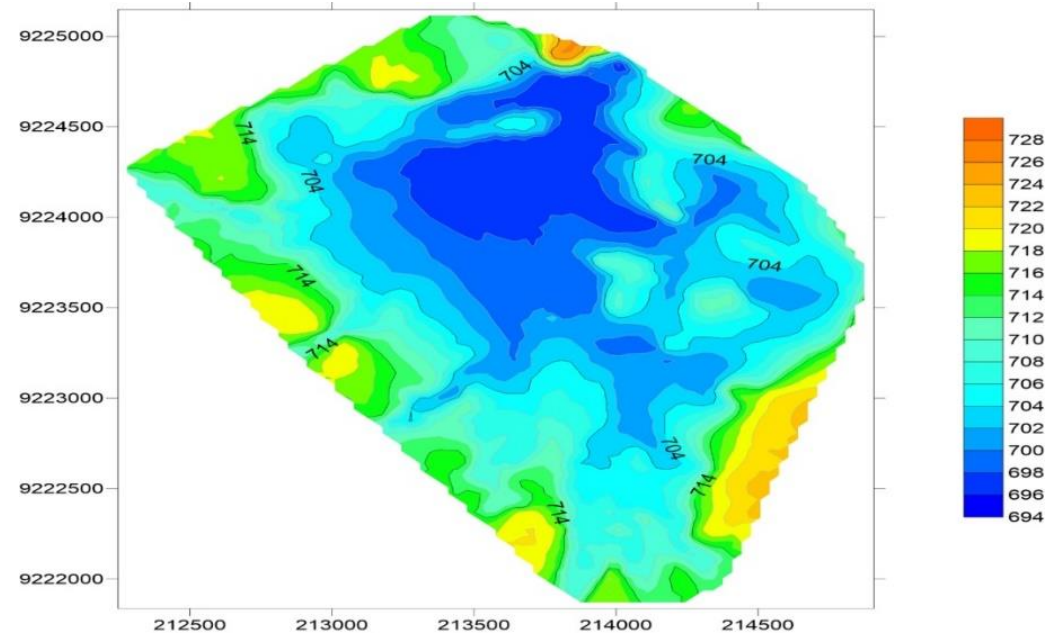

FIGURE 3. Darma Reservoir Elevation and Inundation Conditions 
Normal storage conditions are shown in figure 4 below, namely $712.50 \mathrm{~m}$ elevation, 714 Weir elevation, 713.56 maximum storage elevation, 713.01 flood storage elevation, normal active storage elevation 712.50, inactive storage elevation 703.10, elevation Minimum storage 697.00, Dead storage elevation 693.54

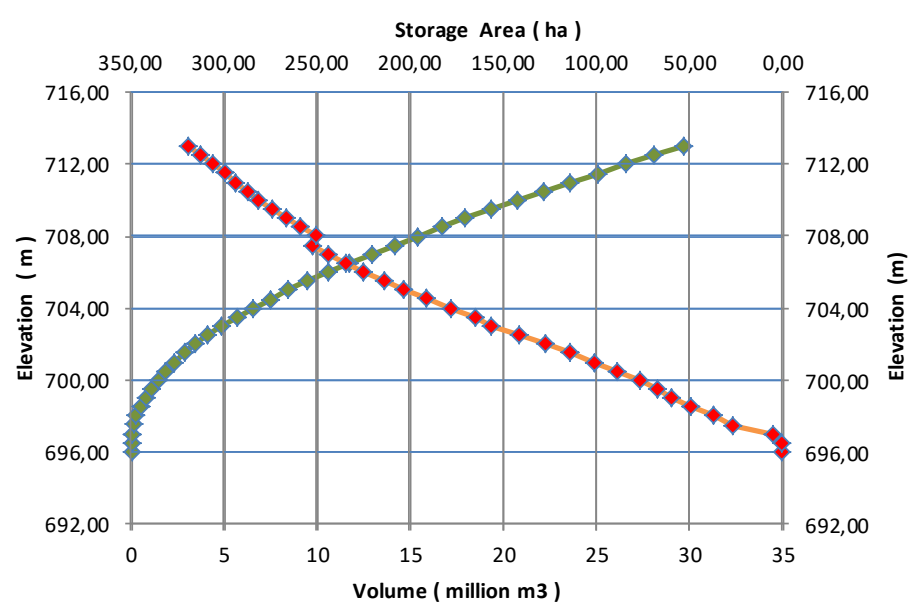

FIGURE 4. Relation of elevation, area, and volume of reservoir in 2020

Figure 4 above, the conditions in 2020 at an elevation of +713.00 elevation are with an area of 319.05 Ha having a volume of 29.664 million $\mathrm{m}^{3}$.

\section{Sediment Volume Analysis}

The volume of sediment that settles at each elevation is indicated by a reduction in the surface area of the elevation and the volume of its storage. With the results of measurements carried out over several years, the difference between the initial storage volume and the actual storage volume was obtained. Calculations from 1988 to 2012 at an elevation of $+712.50 \mathrm{~m}$, the reservoir capacity decreased by 0.967 million $\mathrm{m}^{3}$ from 37.348 million $\mathrm{m}^{3}$ to 36.381 million $\mathrm{m}^{3}$ over 24 years. Calculations from 1988 to 2017 at an elevation of $+712.50 \mathrm{~m}$, the reservoir capacity decreased by 3.002 million $\mathrm{m}^{3}$ from 37.348 million $\mathrm{m}^{3}$ to 34.346 million $\mathrm{m}^{3}$ over 29 years. Calculations from 1988 to 2018 at an elevation of $+712.50 \mathrm{~m}$, the reservoir capacity decreased by 3.200 million $\mathrm{m}^{3}$ from 37.348 million $\mathrm{m}^{3}$ to 34.148 million $\mathrm{m}^{3}$ over 30 years. Calculations from 1988 to 2020 at an elevation of $+712.50 \mathrm{~m}$, the reservoir capacity was reduced by 9.262 million $\mathrm{m}^{3}$ from 37.348 million $\mathrm{m}^{3}$ to 28.086 million $\mathrm{m}^{3}$ over 32 years.

TABLE 3. Sediment Volume Deposited

\begin{tabular}{|c|c|c|c|}
\hline Year & $\begin{array}{l}\text { Time of } \\
\text { Year }\end{array}$ & $\begin{array}{c}\text { Sediment } \\
\text { Volume } \\
\left(\text { million } \mathbf{m}^{3}\right)\end{array}$ & $\begin{array}{r}\text { Sedimentation Rate } \\
\left(\text { million } \mathrm{m}^{3} / \text { tahun }\right)\end{array}$ \\
\hline $\begin{array}{c}1970- \\
1988\end{array}$ & 18 & & 37,327 million $\mathrm{m} 3$ \\
\hline $\begin{array}{l}1988- \\
2012\end{array}$ & 24 & 0,96700 & 36,381 million $\mathrm{m} 3$ \\
\hline $\begin{array}{c}1988- \\
2017\end{array}$ & 29 & 3,00205 & 34,346 million $\mathrm{m} 3$ \\
\hline $\begin{array}{c}1988- \\
2018\end{array}$ & 30 & 3,20000 & 34,148 million $\mathrm{m} 3$ \\
\hline $\begin{array}{c}1988- \\
2020\end{array}$ & 32 & 9,26200 & 28,086 million $\mathrm{m} 3$ \\
\hline
\end{tabular}

From the results of the above analysis, the Darma reservoir has increased the volume of sediment every year. In 2020, the volume of sedimentation that has settled is around 9.26200 million $\mathrm{m}^{3}$. 


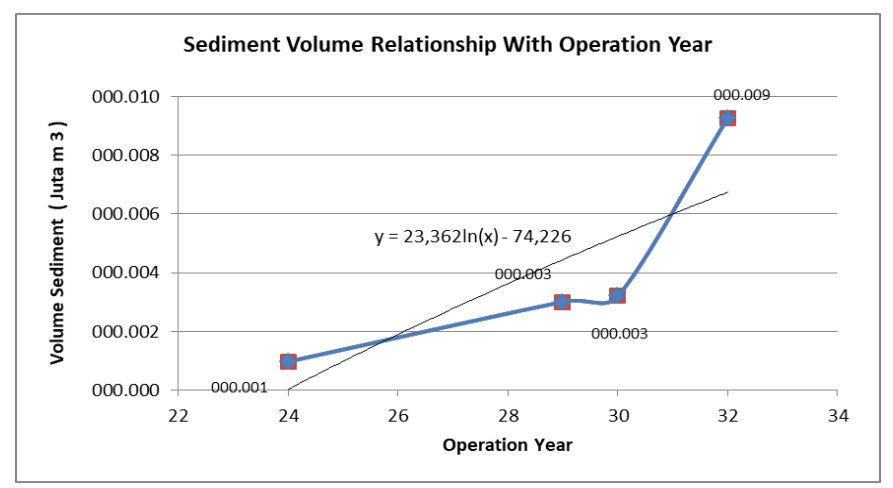

FIGURE 5. Graph of the Relationship between Sedimentation Volume and Year of Operation

\section{Changes in Accumulation of Sedimentation over Time}

The process of operating the reservoir explains that when the highest water level is reached, sediment accumulates in effective capacity or the upstream area of the reservoir. However, when there is a decrease in the water level during the operation of the reservoir, it will cause a current to enter the reservoir, causing the movement of accumulated sediment from the upstream of the reservoir to the body of the reservoir. Sediment accumulation that is cycled continuously leads to an increase in sediment accumulation in the dead storage capacity area.

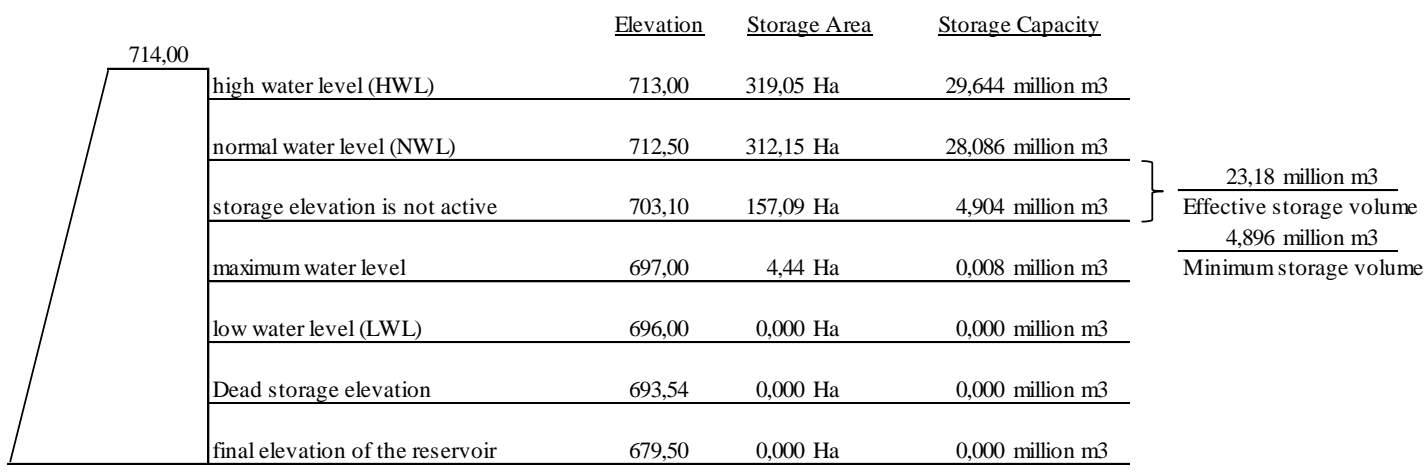

Figure 6. Darma Reservoir Elevation Profile in 2020

The calculation results for 2020 are as in Figure 6 above, the elevation of Normal Active Storage is at elevation of 712.50 with a storage area of 312.15 ha with a storage capacity of 28.086 million $\mathrm{m}^{3}$, elevation of storage is inactive at elevation 703.10 with a storage area of 157.09 ha with a storage capacity of 4.904 million $\mathrm{m} 3$, the minimum storage elevation at an elevation of 697.00 with a storage area of 4.44 ha with a storage capacity of 0.008 million $\mathrm{m}^{3}$, an elevation of dead storage at an elevation of 693.54 with a storage area of 0.00 ha with a storage capacity of 0.000 million $\mathrm{m}^{3}$, then from the above results it can be concluded that for the effective storage volume is 23.18 million $\mathrm{m}^{3}$, while for, inactive storage volume is 4,896 million $\mathrm{m}^{3}$, the minimum storage volume is 0.008 million $\mathrm{m}^{3}$ or $7807.60 \mathrm{~m}^{3}$, the volume dead storage is 0,000 million $\mathrm{m}^{3}$.

\section{Volume and Thickness of Reservoir Sediment Deposits}

Based on the capacity of the Darma Reservoir which is the result of topographic measurements in 1988, 2012, 2017, 2018 and 2020, the reservoir storage volume is at the normal active storage limit $(+712.50)$, as follows: 
TABLE 4. Relationship between Normal Storage and Sediment Deposits

\begin{tabular}{|c|c|c|c|c|}
\hline Year & $\begin{array}{c}\text { Tim } \\
\text { e of } \\
\text { Yea } \\
\text { r }\end{array}$ & $\begin{array}{c}\text { Normal } \\
\text { Elevation }\end{array}$ & $\begin{array}{c}\text { Normal storage } \\
\text { volume }\end{array}$ & $\begin{array}{c}\text { Sediment } \\
\text { Volume }\end{array}$ \\
\hline $\begin{array}{l}1970- \\
1988\end{array}$ & 18 & $712,50 \mathrm{~m}$ & 37,327 million $\mathrm{m} 3$ & \\
\hline $\begin{array}{l}1988- \\
2012\end{array}$ & 24 & $712,50 \mathrm{~m}$ & 36,381 million $\mathrm{m} 3$ & $\begin{array}{l}0,947 \text { million } \mathrm{m} 3 \\
(2,66 \%)\end{array}$ \\
\hline $\begin{array}{l}1988- \\
2017\end{array}$ & 29 & $712,50 \mathrm{~m}$ & 34,346 million $\mathrm{m} 3$ & $\begin{array}{l}3,002 \text { million } \mathrm{m} 3 \\
(8,74 \%)\end{array}$ \\
\hline $\begin{array}{l}1988- \\
2018\end{array}$ & 30 & $712,50 \mathrm{~m}$ & 34,148 million $\mathrm{m} 3$ & $\begin{array}{l}3,200 \text { million } \mathrm{m} 3 \\
(9,37 \%)\end{array}$ \\
\hline $\begin{array}{l}1988- \\
2020\end{array}$ & 32 & $712,50 \mathrm{~m}$ & 28,086 million $\mathrm{m} 3$ & $\begin{array}{l}9,262 \text { million } \mathrm{m} 3 \\
(32,98 \%)\end{array}$ \\
\hline
\end{tabular}

\section{Reservoir Service Life}

Based on the results of the analysis of the storage volume of the Darma reservoir in 2020, it is known in Figure 6. above, the base elevation of the reservoir is at an elevation of 679.50 with a volume capacity of 0 million $\mathrm{m}^{3}$, the elevation of the upper limit of dead storage is at an elevation of 693.54 with a volume capacity of 0 million $\mathrm{m}^{3}$, the lowest elevation is at elevation 696.00 with a volume capacity of 0 million $\mathrm{m}^{3}$, minimum storage elevation at elevation 697.00 with a volume capacity of 0.008 million $\mathrm{m}^{3}$, elevation of storage is inactive at elevation 703.10 with a volume capacity of 4.904 million $\mathrm{m}^{3}$, elevation of active storage normal at elevation, 712.50 with a volume capacity of 28.086 million $\mathrm{m}^{3}$, elevation of flood storage at elevation of 713.00 with a volume capacity of 29.644 million $\mathrm{m}^{3}$. It can be concluded that the sedimentation in the Darma reservoir has exceeded the limit of the base elevation of the reservoir, the dead storage elevation and the lowest elevation, but the reservoir is still functional. The planning age of the Dharma Reservoir to date is 50 years in accordance with the Darma Reservoir development plan.

Therefore, it can be estimated that the dead storage has been exceeded, but currently Darma Reservoir is still functional. This can occur because the material that settles near the extraction building can be taken or flushed by the flow of water that comes out of the inundation area of the reservoir, especially when the valve in the discharge building (irrigation and / or drain valve) is opened.

\section{CONCLUSION}

The carrying capacity of the waters of the Darma Reservoir is $95.296 .470,37 \mathrm{~m}^{3}$, with the assumption that fish cultivators carry out 3 harvests in a year $=12,462.98$ tons / year or 6,231 tons / harvest assuming the harvest occurs three times a year. Based on the results of these calculations, the optimal number of KJA in Darma Reservoir is 1,021 compartments of KJA. Therefore, the presence of KJA with a total of 4,916 in Darma Reservoir has exceeded the carrying capacity of the reservoir. This condition needs the attention of the government and the local community so that it requires a pattern of using the reservoir for community-based fish farming. Cooperation of related agencies with KJA farmers so that the management of feed KJA is formed, improving the skills of KJA human resources, and arranging the layout of KJA in mapping and in the form of written rules. The pattern of utilizing the Darma reservoir for community-based KJA cultivation is a solution in overcoming the increase in the number of KJA, so that it does not threaten the sustainable carrying capacity of community-based KAJ cultivation by issuing business permits so that it can be controlled and does not damage the environment.

The normal storage volume in 2020 is 28.086 million $\mathrm{m}^{3}$, the volume of sediment deposits over a period of 32 years (1988 to 2020) is 9.262 million $\mathrm{m}^{3}$ (32.98\%), the average reservoir sedimentation rate over a period of 32 years $(1988 \mathrm{~s} / \mathrm{d} 2020) \mathrm{Sr}$. amounting to 0.2894 million $\mathrm{m}^{3} /$ year. The sediment volume of the Darma Reservoir has increased and has caused a reduction in the capacity of the reservoir capacity. The results of the analysis of storage volume in 2020 note that the sedimentation in the reservoir has exceeded the limit of the base elevation of the reservoir 679.50, the elevation of dead storage is 
693.54 and the lowest elevation is 696.00 , but the reservoir is still functional. The age of the Darma reservoir to date is 50 years, the beginning of operation was in 1970.

\section{REFERENCES}

[1] I. Ardi, "Budidaya Ikan Sistem Keramba Jaring Apung Guna Menjaga Keberlanjutan Lingkungan Perairan Waduk Cirata," Media Akuakultur, vol. 8, no. 1, p. 23, 2013, doi: 10.15578/ma.8.1.2013.23-29.

[2] S. Wantasen, Sudarmadji, E. Sugiharto, and S. Suprayogi, "Dampak Transformasi Nitrogen Terhadap Lingkungan Biotik di Danau Tondano Provinsi Sulawesi Utara," Mns. dan Lingkung., vol. 19, no. 2, pp. 143-149, 2012.

[3] J. A. Demétrio, L. C. Gomes, J. D. Latini, and A. A. Agostinho, "Influence of net cage farming on the diet of associated wild fish in a Neotropical reservoir," Aquaculture, vol. 330-333, pp. 172-178, 2012, doi: 10.1016/j.aquaculture.2011.11.026.

[4] I. Jubaedah, D. Sudinno, and P. Anas, "Analisis Kondisi Kualitas Air dan Produktivitas Budidaya Keramba Jaring Apung di Waduk Cirata Kabupaten Cianjur Provinsi Jawa Barat," J. Penyul. Perikan. dan Kelaut., vol. 8, no. 1, pp. 9-22, 2014, doi: 10.33378/jppik.v8i1.44.

[5] P. Anas, I. Jubaedah, and D. Sudino, "Kualitas Air dan Beban Limbah Karamba Jaring Apung di Waduk Jatiluhur Jawa Barat PENDAHULUAN Ekosistem perairan waduk terdiri dari komponen biotik seperti ikan, plankton, macrophyta, benthos dan sebagainya yang berhubungan timbal balik dengan ini juga ," vol. 11, no. 1, pp. 35-47, 2017.

[6] R. Rustadi, "Eutrofikasi Nitrogen dan Fosfor serta Pengendaliannya dengan Perikanan di Waduk Sermo," J. Mns. dan Lingkung., vol. 16, no. 3, pp. 176-186, 2009.

[7] H. J. Erlania, Rusmaedi, Prasetio AB, "DAMPAK MANAJEMEN PAKAN DARI KEGIATAN BUDIDAYA IKAN NILA ( Oreochromis niloticus ) DI KERAMBA JARING APUNG TERHADAP KUALITAS,” Pros. forum Inov. Teknol. Akuakultur, no. 2002, pp. 621-631, 2010.

[8] Wesli, “Operasional Waduk,” Teras J., vol. 3, no. 2, pp. 85-94, 2013.

[9] I. Hadihardaja, E. Martha, and I. Soekarno, "Simulasi Dampak Peningkatan,” J. Tek. Sipil, vol. 11, no. 1, pp. 35-46, 2004.

[10] "BATUWARNO, WONOGIRI , JAWA TENGAH Azura Ulfa Slamet Suprayogi Abstract Perhitungan kinerja waduk sangat diperlukan untuk menentukan target manfaat dan kapasitas tampung efektif yang diperlukan . Evaluasi kapasitas waduk diperlukan untuk mengetahui sebera,” pp. 1-12, 2016.

[11] W. Hatmoko and A. Rauf, "Tinggi Muka Air Waduk sebagai Indikator Kekeringan Studi Kasus pada Waduk Kedungombo dan Waduk Cacaban,” Bendungan Besar, pp. 1-15, 2013.

[12] R. D. Lufira and S. Marsudi, “Analisa Uji Model Fisik Pelimpah Bendungan Sukahurip Di Kabupaten Pangandaran Jawa Barat," J. Tek. Pengair., vol. 6, no. 1, pp. 14-21, 2015.

[13] M. A. Ilyas, "Sedimentasi dan dampaknya pada DAS Citarum Hulu," J. Teknol. Lingkung., vol. 3, no. 2, pp. 159-164, 2002, [Online]. Available: http://www.kelair.bppt.go.id/Jt1/2002/vol3-2/11sedim.pdf.

[14] N. Heryani and N. Sutrisno, "Land Use Planning in Catchment Area of Batutegi Reservoir to Reduce Sedimentation,” J. Sumberd. Lahan, vol. 6, no. July, pp. 23-32, 2012.

[15] V. Djajasinga, A. Masrevaniah, and P. T. Juwono, "Kajian Ekonomi Penanganan Sedimen Pada Waduk Seri di Sungai Brantas (Sengguruh, Sutami, dan Wlingi),” J. Tek. Pengair., vol. 3, no. 2, pp. 143-152, 2012. 